\title{
Comparison of bronchoscopic diagnostic techniques with histological findings in brain dead organ donors without suspected pneumonia
}

\author{
Jorge Solé-Violán, Felipe Rodríguez de Castro, Agustín Rey, Jorge Freixinet, Agustín \\ Aranda, José Caminero, José Bolaños
}

\begin{abstract}
Background - The techniques for recognising pneumonia in mechanically ventilated patients were evaluated as no "gold standard" is available to establish the diagnosis in these patients.

Methods - A prospective study was performed on nine brain dead organ donors not suspected of having pneumonia to assess the specificity of bacteriological results from different samples by comparing them with the histological findings from an open pulmonary biopsy specimen taken immediately after death through a mini-thoracotomy.

Results - Seven of the nine organ donors without clinical evidence of pulmonary infection and not on antibiotic therapy showed histological features of bronchopneumonia. There was no association between the histological findings and quantitative cultures of the lung biopsy specimen.
\end{abstract}

Conclusions - Histological evidence of pneumonia was common in this group of ventilated patients who had no clinical signs of the disease.

(Thorax 1996;51:929-931)

Intensiva

J Solé-Violán

J Freixinet

A Aranda

$\mathrm{J}$ Bolaños

Sección de

Neumología

F Rodriguez de Castro

$\mathrm{J}$ Caminero

Servicio de Anatomía Patológica

A Rey

Hospital Universitario "Ntra. Sra. del Pino", Universidad de Las Palmas de Gran

Canaria (ULPGC),

Las Palmas de Gran

Canaria, Spain

Correspondence to: Dr F Rodríguez de Castro, Sección de Neumología, Hospital Universitario "Ntra. Sra. del Pino", Angel Guimerá 93, 35005 Las Palmas de Gran Canaria Spain.

Received 4 July 1995 Returned to authors 3 October 1995

Revised version received

19 February 1996

Accepted for publication

1 March 1996
Keywords: protected specimen brush biopsy, bronchobiopsy, brain dead organ donors.

We have shown that up to $18 \%$ of protected specimen brush biopsies and bronchoalveolar lavage specimens yield significant bacterial growth in ventilated patients without evidence of pulmonary infections ${ }^{1}$ and have suggested that these findings may be a feature common to most patients who undergo prolonged mechanical ventilation. This prompted us to perform a prospective study to assess the significance of these results by comparing them with the findings obtained in a pulmonary biopsy specimen taken immediately after death in ventilated brain dead organ donors not suspected of having pneumonia.

\section{Methods}

PATIENTS care unit (ICU) who were not suspected of having pneumonia participated in a prospective study. None had fever, leucocytosis, evidence of pulmonary infiltrates on chest alveolar lavage, intracellular organisms, pulmonary

Nine brain dead organ donors in the intensive radiographs, or had received antibiotics. All patients had had an endotracheal tube in place for at least 24 hours. At the outset $10 \mathrm{ml}$ of sterile $0.9 \%$ saline was aspirated through the suction channel of the bronchoscope for bacteriological examination.

\section{SPECIMEN COLLECTION}

Both protected specimen brush biopsy and bronchoalveolar lavage were performed in the superior segment of the lower right lobe through a fibreoptic bronchoscope as previously described. ${ }^{12}$ A large specimen (approximately $3 \mathrm{~cm}^{3}$ ) was then cut from the superior segment of the lower right lobe through a mini-thoracotomy. This biopsy sample was sectioned into two fragments, one for bacteriological examination and the other for pathological processing.

The study was approved by the local research ethics committee and informed consent was obtained in all cases.

MICROBIOLOGICAL PROCESSING OF SPECIMENS Specimens were transported immediately to the laboratory and processed for quantitative bacterial and fungal culture using standard methods as described in previous studies. ${ }^{12}$ Biopsy samples were weighed, covered with $1 \mathrm{ml}$ of sterile saline, and homogenised. An aliquot of $0.1 \mathrm{ml}$ was inoculated onto the same plates as those used for the protected specimen brush biopsy and bronchoalveolar lavage. Bacteriological counts for the biopsy specimens were expressed as colony forming units per gram of tissue $(\mathrm{cfu} / \mathrm{g})$ with counts of $\geqslant 10^{3}$ $\mathrm{cfu} / \mathrm{g}$ being considered significant.

CYTOPATHOLOGICAL STUDY

Two $0.5 \mathrm{ml}$ samples of resuspended original bronchoalveolar lavage fluid were cytocentrifuged and stained for cell identification, differential counting, and estimation of the percentage of cells with intracellular organisms as described in previous studies. ${ }^{2}$ Tissue blocks were embedded in paraffin and cut into sections of $4 \mu \mathrm{m}$. At least 10 sections were obtained per sample. The presence or absence of bronchopneumonia was determined according to the criteria described by Rouby et al. ${ }^{3}$ Two different pathologists evaluated all histological specimens without knowing the study protocol.

Results

The mean (SD) age of the nine donors (six men) was 37.6 (16.2) years (range 20-63 
Table 1 Histological and bacteriological findings of nine brain dead organ donors without suspected pneumonia

\begin{tabular}{|c|c|c|c|c|c|c|c|c|c|}
\hline Diagnosis & $\begin{array}{l}\text { Age } \\
(y r)\end{array}$ & Sex & $M V(h)$ & $\begin{array}{l}F B / \\
L B(h)\end{array}$ & $P S B(c f u / m l)$ & $B A L(c f u / m l)$ & $I C O$ & $L C(c f u / m l)$ & Histology \\
\hline $\begin{array}{l}\text { Cerebral } \\
\text { haemorrhage }\end{array}$ & 49 & $M$ & 33 & 6 & Sterile & $\begin{array}{l}4 \times 10^{4} \\
S \text { pneumoniae }\end{array}$ & $4 \%$ & - & $\begin{array}{l}\text { Focal } \\
\quad \text { bronchopneumonia }\end{array}$ \\
\hline $\begin{array}{l}\text { Subarachnoid } \\
\text { haemorrhage }\end{array}$ & 36 & $\mathrm{~F}$ & 88 & 0 & Sterile & $10^{5} S$ viridans & $0 \%$ & Sterile & $\begin{array}{l}\text { Confluent } \\
\text { bronchopneumonia }\end{array}$ \\
\hline Cranial trauma ${ }^{\star}$ & 63 & $\mathrm{~F}$ & 72 & 0 & $10^{2} S$ aureus & $\begin{array}{l}8 \times 10^{5} \\
\quad H \text { influenzae } \\
5 \times 10^{5} S \text { viridans } \\
9 \times 10^{5} S \text { aureus }\end{array}$ & $0 \%$ & $\begin{array}{l}10^{3} \mathrm{H} \text { influenzae } \\
10^{3} \mathrm{~K} \text { oxytoca } \\
10^{2} \mathrm{~S} \text { viridans }\end{array}$ & $\begin{array}{l}\text { Focal } \\
\text { bronchopneumonia }\end{array}$ \\
\hline Cranial trauma & 20 & $M$ & 168 & 0 & Sterile & Sterile & $3 \%$ & Sterile & Normal \\
\hline Cranial trauma & 31 & $\mathbf{M}$ & 240 & 1.5 & Sterile & $\begin{array}{l}10^{4} \text { Citrobacter } \\
\quad \text { diversus } \\
5 \times 10^{3} S \text { viridans }\end{array}$ & $0 \%$ & Sterile & Normal \\
\hline Cranial trauma & 61 & $\mathrm{~F}$ & 89 & 0 & Sterile & $\begin{array}{l}2 \times 10^{4} \\
P \text { aeruginosa } \\
2 \times 10^{4} S \text { aureus }\end{array}$ & $3.4 \%$ & Sterile & $\begin{array}{l}\text { Focal } \\
\quad \text { bronchopneumonia }\end{array}$ \\
\hline Cranial trauma & 23 & $M$ & 72 & 9 & $\begin{array}{l}10^{5} P \text { aeruginosa } \\
10^{5} S \text { aureus } \\
5 \times 10^{4} S \text { viridans }\end{array}$ & $\begin{array}{l}10^{5} P \text { aeruginosa } \\
10^{5} S \text { aureus } \\
5 \times 10^{4} S \text { viridans }\end{array}$ & $36 \%$ & $10^{3} S$ aureus & $\begin{array}{l}\text { Confluent } \\
\text { bronchopneumonia }\end{array}$ \\
\hline Cardiac arrest & 24 & $M$ & 84 & 0 & $\begin{array}{l}4 \times 10^{3} \\
S \text { maltophila }\end{array}$ & Sterile & $30 \%$ & Sterile & $\begin{array}{l}\text { Confluent } \\
\text { bronchopneumonia }\end{array}$ \\
\hline
\end{tabular}

$\mathrm{M}=$ male; $\mathrm{F}=$ female; $\mathrm{MV}=$ period of mechanical ventilation; $\mathrm{FB} / \mathrm{LB}=$ time between fibreoptic bronchoscopy and lung biopsy; cfu = colony forming units; PSB = protected specimen brush; BAL = bronchoalveolar lavage; $\mathrm{ICO}=$ intracellular microorganism; LC = lung culture.

$\star$ Patients with purulent tracheobronchial secretions.

years). The cause of brain death was head injury in six cases, cerebrovascular disease in two, and cardiac arrest in one (table 1). The mean duration for which patients were mechanically ventilated was 93.1 (68.4) hours (range 33-240) and the mean time lapse from fibreoptic bronchoscopy to thoracotomy was 2.66 (3.73) hours. Arterial blood gas analysis showed a $\mathrm{PaCO}_{2}$ of $5(1.6) \mathrm{kPa}, \mathrm{pH}$ of 7.37 (0.03), and $\mathrm{PaO}_{2}$ of 47.3 (14.6) $\mathrm{kPa}$ with an $\mathrm{FiO}_{2}$ of $100 \%$. Fibreoptic bronchoscopy was considered normal in seven cases and purulent bronchial secretions were noted in the remaining two patients. None had received antibiotics. The mean axillary temperature was 36.5 $(0.75)^{\circ} \mathrm{C}$ and the mean white blood cell count was $8.5(2.0) \times 10^{9} / 1$.

The histological and bacteriological results are shown in table 1 . The average percentage of bronchoalveolar fluid retrieved was $30 \%$ (range 15-45\%). Contamination by squamous epithelial cells was less than $1 \%$ of the total number of cells recovered by lavage in all cases. The percentage of neutrophils recovered by lavage was $70.6(31.1) \%$ and the percentage containing intracellular organisms was 20.7 (27.1)\%. Only in three patients were infected cells not observed.

\section{Discussion}

The main finding of this study is that seven out of nine donors with no clinical evidence of pulmonary infection who were not receiving antibiotic therapy showed characteristic lesions of bronchopneumonia (fig 1). To our knowledge, these findings have not previously been reported in patients not suspected of having pneumonia.

We have previously studied the results of protected specimen brush and bronchoalveolar lavage cultures in ventilated patients without clinical suspicion of pneumonia ${ }^{1}$ and found a significant percentage of patients with a moderate or high bacterial growth in specimens obtained from the distal airways. It was not clear whether these findings represented a limitation of the diagnostic techniques or were a feature present in many patients who undergo prolonged mechanical ventilation From the present results the latter hypothesis seems to be the most probable. As stated by Carlet, ${ }^{4}$ two types of pneumonia are found in ventilated patients - one localised but extending rapidly which has a poor prognosis and the other a diffuse bronchopneumonia which is often subacute and may resolve without antibiotic therapy. An alternative explanation would be that, since it may take several days for

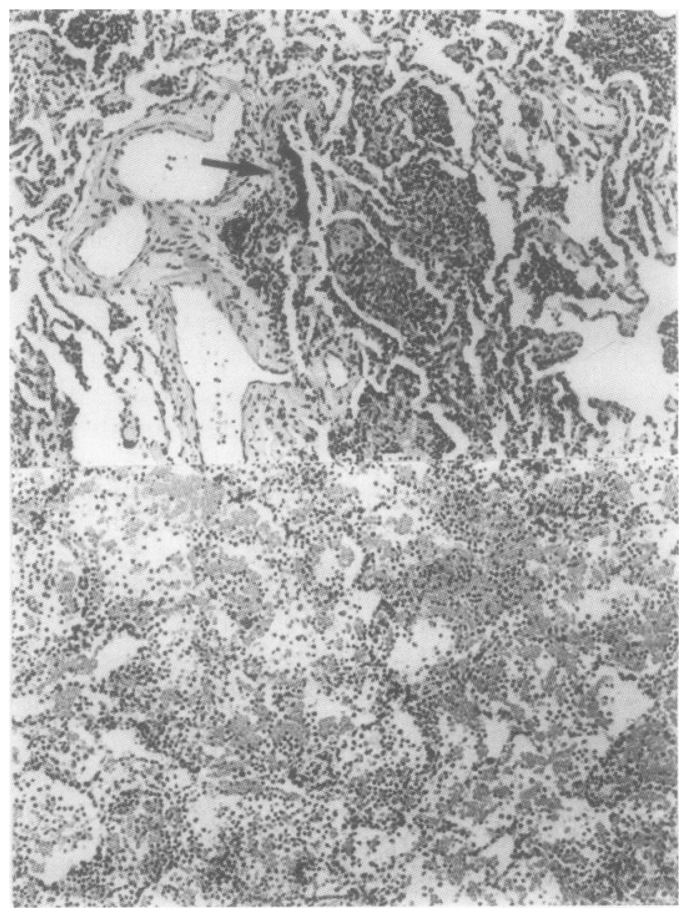

Figure 1 Top: Focal bronchopneumonia. An acute inflammatory infiltrate can be seen beneath a residual laye of bronchiolar epithelium (arrow) limited to a few alveoli. Stain: haematoxylin and eosin; original magnification $\times 100$. Bottom: Confluent bronchopneumonia. The alveolar spaces show haemorrhage and moderate polymorphonuclear leucocyte accumulation within a large pulmonary area. Stain: haematoxylin and eosin; original magnification $\times 100$. 
pneumonia to become clinically evident, these findings may simply represent the early identification of pneumonia. In fact, in our previous study we found that four of six patients with a significant growth in both protected specimen brush biopsy and bronchoalveolar lavage specimens subsequently developed pneumonia. Others ${ }^{56}$ have found a high and constant rate of acquisition of nosocomial pneumonia in the first 8-10 days of intubation with a low rate thereafter. The pathogenetic explanation for this high initial risk is not known. It is possible that the initial period in the ICU involves the interaction of several factors, particularly the prior risk of aspiration which may occur at the start of intensive therapy, just before or during tracheal intubation. The high incidence of inhalation of gastric contents and/or blood in brain dead organ donors should also be emphasised. $^{7}$

We observed a poorer yield of positive results by protected specimen brush biopsy than with bronchoalveolar lavage which may provide a better reflection of the lung's bacterial burden. Moreover, we did not find any association between the histological findings and quantitative cultures from lung biopsy specimens (table 1). This has also been observed by Rouby $e t a l^{\beta}$ and Torres et al and may be due to the effect of antibiotics and the non-homogeneous distribu- tion of bacteria infecting the lung parenchyma. As the bacterial burden can vary considerably from one zone to another, it is possible that lung culture, bronchoalveolar lavage, and protected specimen brush biopsy may be sampling different areas of the lung from that sampled during the pneumonectomy immediately after death and may explain our findings.

1 Rodríguez de Castro F, Solé J, Elcuaz R. Quantitative cultures of protected brush specimens and bronchoalveolar cultures of protected brush specimens and bronchoalveolar
lavage in ventilated patients without suspected pneumonia. Am f Respir Crit Care Med 1994;149:320-3.

2 Solé J, Rodríguez de Castro F, Rey A, Martín JC, Cabrera P. Usefulness of microscopic examination of intracellular organisms in lavage fluid in ventilator-associated pneumonia. Chest 1994;106:889-94.

3 Rouby JJ, Martin de Lassale E, Poete P, Nicolas MH, Bodin $\mathrm{L}$, Jarlier V, et al. Nosocomial bronchopneumonia in the critically ill. Histologic and bacteriologic aspects. Am Rev critically ill. Histologic and bacte

4 Carlet J. Controversies about the diagnosis and incidence of nosocomial pneumonia in ICU patients. Intensive Crit Care Digest 1991;10:32-3.

5 Langer $M$, Mosconi P, Cigada $M$, Mandell $M$. The Intensive Care Unit Group of Infection Control. Longterm respiratory support and risk of pneumonia in term respiratory support and risk of pneumonia in
critically ill patients. Am Rev Respir Dis 1989;140:302-5.

6 Joshi N, Localio AR, Hamory BH. A predictive risk index for nosocomial pneumonia in the intensive care unit. $A m \mathcal{F}$ Med 1992;93:135-42.

7 Riou B, Guesde R, Jacquens Y, Duranteau R, Viars P. Fiberoptic bronchoscopy in brain-dead organ donors. $\mathrm{Am}$ f Respir Crit Care Med 1994;150:558-60.

8 Torres A, El-Biary M, Padró L, Gónzalez J, Puig de la Bellacasa J, Ramírez J, et al. Validation of different techniques for the diagnosis of ventilator-associated pneumonia. Comparison with immediate postmortem pulmonary biopsy. Am F Respir Crit Care Med 1994;149:324-31. 